\title{
Implementation of Geographical Information System for Bacteriological Contamination Analysis on Refill Drinking Water Depot (Study in Tembalang District)
}

\author{
Amelia Rahmitha ${ }^{1,{ }^{*}}$, Endang Sri Utami ${ }^{1}$, Marya Yenita Sitohang ${ }^{1}$ \\ ${ }^{1}$ Bachelor Program of Public Health, Diponegoro University, Semarang - Indonesia
}

\begin{abstract}
People used refilled-drinking-water for household and food stall because its efficient and low cost. Based on Indonesian Health Ministry regulation, it should not have any coliform bacteria. This study aimed to describe the bacteriological contamination of refilled drinking water using geographical information system (GIS). In this research, it was used an analytic observational method. The samples were from all available (37) depots in Tembalang district, one form each depot took used a sterile bottle. Contamination of bacteria was identified by Most Probable Number (MPN) method lactose broth media, Mac Conkey media, and IMVIC media. The depot samples were then plotted on (GIS). This study showed 95\% samples were not feasible to consume since they contamined coliform. All sub-district had one that contaminated by coliform, $75 \%$ sub-districts had depots that contaminated Escherichia coli, while 55\% subdistricts had depots that contaminated with other bacteria. The internal risk factors of the contamination were the absence of hygiene-sanitation worthy certificate (95\%), depots location near to pollution sources (5\%), and the misused of UV light. The external risk factor was lack of quality control that was not as the sterilization from office health Semarang city. Policy reinforcement should be done to all of the depots.
\end{abstract}

\section{Background}

Drinking water is water that goes through the processing or without processing that required of health and can be directly drunk. Safe supply of drinking water is essential for human life and should not pose a significant risk to humans[1].The requirement quality of drinking water have to be followed and obeyed by all producers so that drinking water is safe for consumption. These requirements include physical, microbiological, chemical, and radioactive aspects[2]. Biological parameters are directly related to health. The regulation on Minister of Health Republic of Indonesia number 492/Menkes/Per/IV/2010 are Escherichia coli and total bacteria coliform maximum allowable is 0 per $100 \mathrm{ml}$ sample[2].

Escherichia coli that such pathogens can be transmitted through water and food contamination, and contact with people[3]. Escherichia coli that contaminate water has a risk to consumers, such as diarrhea[4]. According to the Health Profile of Semarang City, Incidence Rate of diarrhea is 25 per 1,000 population in 2014. Meanwhile, worldwide according to UNICEF Indonesia, $88 \%$ of children die since diarrhea[5]. Coliform bacteria are organisms in the environment and the feces of warm-blooded animal and human. The presence of coliform in drinking water indicates that disease-causing organisms (pathogens) can occur through the water system [6].

Nowadays, refilled drinking water has become a common choice by middle-income people[7]. The water is produced by the Drinking Water Refilled Depot: a business entity that manages drinking water for public purposes in bulk and not packaged[8]. The refilled drinking water business is growing well due to the higher price of bottled mineral water. However, the process of refill drinking water uses the same technology as bottled mineral water. However, refilled drinking water does not use packaging and distribution costs.[7].

Tembalang Sub-district of Semarang City has 156.865 people in 2015[9]. This area is a densely populated area due to the development of several campuses such as Diponegoro University, Poltekkes, Pandanaran University, University of Muhammadiyah Semarang, Husada School of Health Sciences and AsihHusada Health Academy. This condition increased demand for drinking water, both in terms of quality and quantity so that the risk of decreased feasibility and safety of drinking water due to contamination of microorganisms. Based on a survey conducted by the author, the number refilled drinking water depot in Tembalang sub-district is 37 depots.

The more use for the vital needs of the community and the indication of the lack of safety refilled drinking water depot, it is necessary to supervise or monitor and

Corresponding author: rahmithahelmi@gmail.com 
adequate testing. To determine whether or not the condition is contaminated, clinical research or testing in the laboratory is needed [10]. To ensure adequate water to consume, there are several point to note: regulatory compliance, the ability of a water laboratory to conduct complete and accurate water testing and analysis, proper operation and maintenance of water purification equipment, local health service skills for sanitation surveying and monitoring water quality, water source protection programs, and strong information campaigns to keep water safe at home [11]. In 2016, microbiological quality test was conducted by Semarang City Health Office 14 by sampling, the result is $100 \%$ sample containing total coliform and $14,3 \%$ sample containing E. coli[12]. This condition because not all depots to do the processing properly and correctly [13]. In addition, only 2 of 37 DAMIUs have sanitation sanitation-worthy certificates [14].

Based on the background, it is necessary to test bacteriological contamination on refilled drinking water in Tembalang Sub-district. The laboratorium result will be implemented on Geograpghical Information System (GIS) to describe the contamination of Escherichia coli and coliform contamination. Literally, GIS is a component consisting of hardware, software, geographic data and human resources that effectively to capture, store, repair, update, manage, manipulate, integrate, analyze, and display data in any information geographically based. [15]. In this study, GIS is used to visualize microbiological analysis on depots products in Tembalang Sub-district in map form. It is very efficient for storing and communicating geographic information[16].

\section{Method}

This study used observational analytic method in Tembalang Sub-district of Semarang City from April to June 2017. Samples were taken in each depot using sterile bottles with total of 37 depots in Tembalang Subdistrict. To test the consistency of the results, this study conducted two laboratory tests at 2 -month intervals. The first study used 37 samples and the second study used 29 samples. This is because as many as 8 depot owners are unwilling to do second phase testing. Unstructured interviews were also conducted on depot owners and observations around depots location. Coliform contamination was identified using the Most Probable

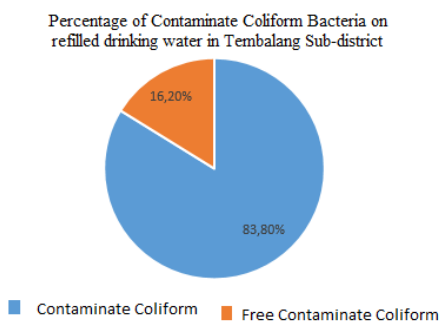

a
Number (MPN) method on the lactose broth medium. Further positive results were tested with Mac Conkey media to identify Eschericha $s p$. To know Eschericha coli species used IMVIC method. Samples of drinking water depots were subsequently plotted using Geographical Information System (GIS).

\section{Results}

The test was conducted twice to the product samples in Tembalang sub-district in April and June 2017. The first test was successful in examining 37 samples but in the second test only 29 samples were tested because 8 depots owners refused to return to sample.

The table above shows that the presence of coliform bacteria in the drinking water refill sample has decreased from the first test to the second test. As for the presence of Escherichia coli showed improvement. Based on the result of paired T-test, it was found that there was no difference of first and second sample test result $(\mathrm{p}>$ $0,05)$. In water samples also showed contamination of Escherichiavalneris, Escherichiafergusonii, Staphylococcus, Enterobacter and Pseudomonas bacteria which consisted in the same sample both at the first and second test. Therefore it can be concluded that there is consistency in the test results so that in this study used 37 samples from the first test results.

Table 1. The results of Coliform and Escihierichia coli on the first and second tests on refilled drinking water in Tembalang Sub-district

\begin{tabular}{|c|c|c|c|c|}
\hline \multirow{3}{*}{ Test } & \multicolumn{4}{|c|}{ Status of Bacteriology } \\
\cline { 2 - 5 } & \multicolumn{2}{|c|}{ Coliform } & \multicolumn{2}{c|}{ Escherichia coli } \\
\cline { 2 - 5 } & $\begin{array}{c}\text { Not } \\
\text { Qualify }\end{array}$ & Qualify & Positive & Negative \\
\hline $1^{\text {st }}$ & $\begin{array}{c}23 \\
(79,3 \%)\end{array}$ & $\begin{array}{c}6 \\
(20,7 \%)\end{array}$ & $\begin{array}{c}9 \\
(31 \%)\end{array}$ & $\begin{array}{c}20 \\
(69 \%)\end{array}$ \\
\hline $2^{\text {nd }}$ & 21 & 8 & 13 & 16 \\
& $(72,4 \%$ & $(27,6 \%)$ & $(44,8 \%)$ & $(55,2 \%)$ \\
\hline
\end{tabular}

\subsection{Contamination of bacteriology at refilled drinking water depot}

Laboratory test on microbiological quality parameters of refilled drinking water in Tembalang Sub-district. These microbiological parameters are total coliform and Esherichiacoli.

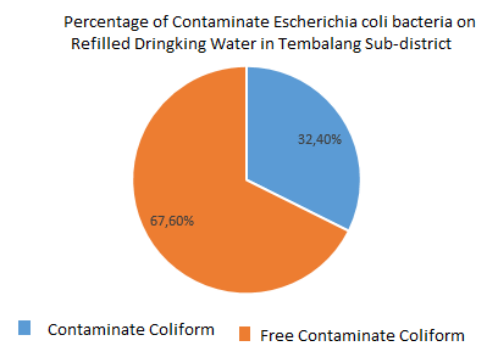

b

Fig.1. Contamination of coliform (a) and Esherichia coli (b) at refilled drinking water in TembalangSubdistrict 
Based on Figure 1 shows that most of refilled drinking water contaminated coliform exceeding the maximum limit as recommended in Permenkes RI Number 492/MENKES/PER/IV/2010 is $0 / 100 \mathrm{ml}$ water sample. While less than some refilled drinking water proven contaminated Escherichiacoli bacteria.

\subsection{Map of bacteriology contamination at the refilled drinking water depot}

The distribution of bacteriological contamination at at refilled drinking water from depots in Tembalang Subdistrict is described using Geographical Information System (GIS). The distribution map is shown in the following figure.

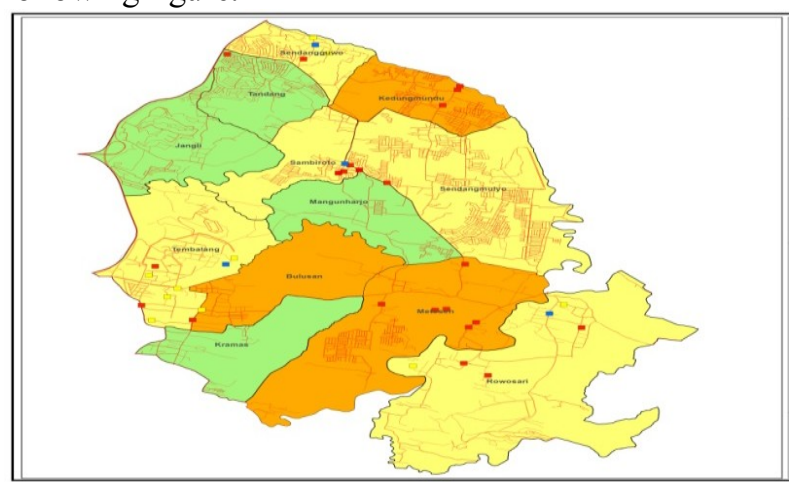

Fig. 2. Map Distribution of Coliform Bacteria at AMIU in Tembalang Sub-district

The analysis was performed by calculating the percentage of depots containing positive bacteria on all depots examined in the villages. After that the villages is categorized in the following categories:
$0 \quad$ : Free of Pollution
$1-33 \%$ : Light Pollution
34-66\%: Medium Pollution
67-100\%: Heavy contamination

Based on figure 2 shows that from 37 depots, 3 villages namely Meteseh, Bulusan and Kedungmundu are in medium contamination category, while Tembalang, Rowosari, Sendangmulyo, Sendangguwo and Sambiroto villages are included in medium contamination.

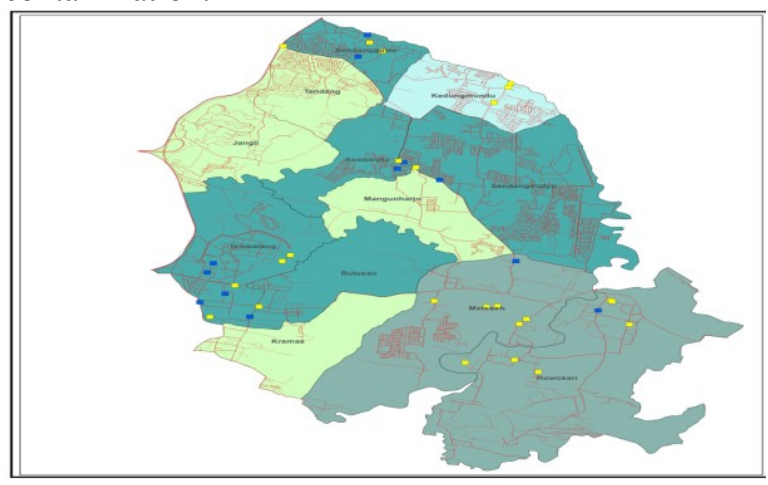

Fig. 3. Map of E. coli Bacteria Distribution at AMIU in Tembalang District

Villages based on the risk of contamination are classified into high risk (MPN>100), medium (MPN 10-
100) and low (MPN 1-10). In Figure 3 it is known that 2 villages has drinking water contains mild E.coli bacteria ie in Rowosari and Meteseh. While for the medium category is Sendangguwo, Sendangmulyo, Sambiroto, and Tembalang. Based on Figure 4, bacteriologic effects of drinking water can also identify other bacteria $E$. fergusoni, E.valneris, Enterobacter, Pseudomonas andStaphylococus. The villages covering the light category is in Rowosari, Sambiroto and Sendangguwo. While for the medium category is Sendangmulyo and Tembalang.

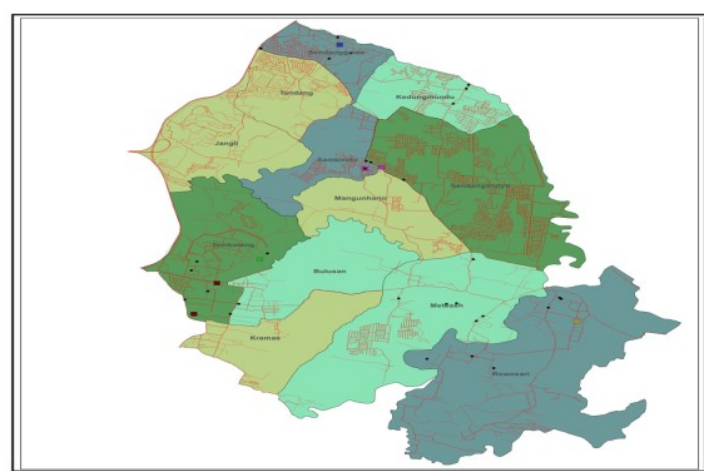

Fig. 4. Map of Bacteria Distribution at depots in Tembalang Sub-district

\section{Discussion}

The existence of the bacteria Coliform and Escherichiacoli at refilled drinking water in Tembalang District can be caused by various factors. Here's an explanation of some of the risk factors for the contamination:

\subsection{External Factors}

External factor at risk for bacteriological contamination at refilled drinking water is the quality control of drinking water produced by depot less than optimal. This observation is conducted by District Health Office which includes sanitation inspection, drinking water sampling at least 1 month 1 time[19].

Based on the condition of the field shows that the District / Municipal Health Office performs inspection and sampling so it is not comprehensive in supervising the quality of depot circulating in the community. This shows that the implementation of the program has not been in accordance with the regulation of Minister of Health RI Number 43 Year 2014about Hygiene Sanitation Drinking Water Depot. Things that affect the condition in accordance with the Health Department of Semarang City Data is related to Human Resources (HR) and funds. The results show that by 2016, the number of depots under surveillance is 13 of the 37 in Tembalang Sub-district. 


\section{2 Internal factors}

Internal factors at risk for bacteriological contamination in refilled drinking water can be derived from itself. Internal factors include sanitation hygiene. Depot sanitation hygiene is an effort to control the risk factor of contamination from place, equipment and handler to drinking water for safe consumption[19]. Based on the data of the health office of Semarang City 2016 shows that the depot that has certificate of sanitary hygiene is only 2. Aspects of hygiene sanitation observed by researchers include:

\subsubsection{Location}

Locations used for depots should be in areas that are free from contamination, ie away from pollution areas such as puddles and swamps, sewerage and garbage, accumulation of junk or hazardous and toxic materials (B3). In addition, the site should also be away from polluting areas such as paint workshops, welding, limestone, asbestos and the like as well as public sewerage sites, bus terminals or other pollution-intensive areas ${ }^{[17]}$.

Based on the Regulation of the Minister of Health No. 1096/MENKES/PERVI/2011 on hygiene and sanitation of catering services, the location of food processing from the source of pollution is at least 500 meters ${ }^{[18]}$. Field observations indicate that there are 2 depots $(15 \%)$ located near motor and car repair shops.

\subsubsection{Use of ultra violet lamp}

Ultra Violet (UV) lamps is used for the disinfection process. Disinfection is an attempt to shut down the remaining microorganisms in the process, especially addressed to the pathogen. Disinfection is intended to kill pathogic germs contained in water so that drinking water produced is safe to drink.Observations show that most depots do not light UV light in drinking water treatment processes.

\subsubsection{Behavior of handkerchief}

The handler is the person who directly handles the drinking water management process at depot to serve the consumers. A handler must have good personal hygiene such as not smoking or scratching body parts while serving customers, washing hands before serving customers and using clean and decent clothing. The observation results show that only $10 \%$ of owner depots have a handyman with good personal hygiene. This is due to lack of training or notice so that the handlers do not have sufficient knowledge. In addition, the lack of facilities also affects the application of personal hygiene by the handlers.

\section{Conclusion}

This research uses depots 31 samples from Tembalang sub-districts which is a densely populated area and campus development area. Through laboratory test results on 37 samples, it was found that $83.8 \%$ of samples contained coliform bacteria and $32.4 \%$ of depot products were contaminated with Escherichia coli bacteria. Based on GIS analysis found contamination of coliform bacteria in depots in 3 villages classified as heavy $(100 \%)$. While the contamination of bacteria Escherichiacoli exist in depots in 3 villages with different categories. Contamination of Escherichiasp bacteria other species only not found in depot in Bulusan village and contamination of gram positive bacteria $(+)$ only not found in depot in Kramas village. Other types of Escherichia bacteria encountered were Escherichia valnerisand Escherichia fergusonii. However, the type of gram-positive bacteria can not be determined because of laboratory tests that do not further identify the type of bacteria.

\section{Suggestion}

- For the Government: it is expected to provide regulation for depot to maintain the quality of refilled drinking water products through maintaining and improving the quality of sanitation as well as conducting inspection of drinking water in the laboratory on a regular basis that is at least 6 months. In addition, the government must also conduct equity in order to check on depots done in all places and not only in certain places.

- For the owner of depots: it is expected to maintain the quality of refill drinking water products through maintaining and improving the quality of sanitation as well as conducting periodic inspection of drinking water in the laboratory

- For the Community: more vigilant in drinking water consumption, and wise to choose producer refilled drinking water.

- For Researchers: expected to be able to conduct further research to develop science and dedication to improve the quality of life of the community, especially the health of the local community.

\section{References}

1. WHO (World Health Organization). Fourth edition drinking water guidelines. World Health Organization, Geneva. (2011)

2. Depkes. Regulation of the Minister of Health of the Republic of Indonesia Number 492/Menkes/Per/IV/2010 Concerning the Quality of Drinking Water. Ministry of Health of the Republic of Indonesia. (2010)

3. CDC. Escheria coli. Https://Www.Cdc.Gov/Ecoli/General/Index.Html Accessed on 16 June 2017. (2015).

4. BPOM.Dangers of Microbes On Packaging Water. http://Ik.Pom.Go.Id/V2014/Artikel/Bahaya- 
Mikroba-Pada-Air-Kemasanfinal.Pdf Accessed on 16 June 2017. (2014).

5. UNICEF Indonesia. Water Supply, Sanitation and Sanitation. Jakarta: UNICEF Indonesia. (2012).

6. The Washington Health Ministry.Coliform Bacteria In Drinking Water. Http://Www.Doh.Wa.Gov/Communityandenvironm ent/Drinkingwater/Contaminants/ColiformAccessed on 16 June 2017. (2017).

7. Keman, Soedjajadi. Folia MedicaIndonesiana, Vol. 41 No. 1 .(2005).

8. Rb. Tombeng, B. Polii, S. Sinolungan. Journal of Public Health of Sam Ratulangi University. Agustus 2013;1(7) (2005)

9. BPS Semarang City. City of Semarang in Figures 2016 Semarang: BPS Kota Semarang (2016)

10. Rumondor, P Perisai, JohnPorotu'o, and Olivia Waworuntu, JurnalE-Biomedik (Ebm). Volume 2, No 2(2014)

11. Magtibay. Water refilling station: an alternative source of drinking water supply in the Philippines. Acessed 8 July 2017.http://wedc.lboro.ac.uk/resources/conference/3 0/Magtibay.pdf(2004).

12. Semarang City Health Office. Semarang City Rechargeable Water Quality Inspection Results 2016. Not published. (2016)
13. Nuria, Maulita Cut dkk. Test of Escherichia Coli Bacteria In Drinking Water Refill From Recharge Depot In Kabupaten Rembang. Yogyakarta :Universitas Gadjah Mada.Vol 5. No 1. Page 27 35. (2009)

14. Semarang City Health Office. List of Certificate of Sanitation Hygiene Worthy of Drinking Water Refills in Semarang City 2016. Not published. (2016)

15. Puntodewo, Atie. Geographic Information System for Natural Resource Management. Center For International Forestry (2003).

16. Doktafia. Geographic Information System(GIS). http://doktafia.staff.gunadarma.ac.id/Downloads/file s/30525/SISTEM+INFORMASI+GEOGRAFIS++1 .pdfAccessed on 4 May 2017. (2017)

17. Sabariah. Influential Factors Against Water Contamination Refill by Escherichia Coli in Denpasar City. Bali: Udayana University. (2016)

18. Ministry of Health RI. Regulation of the Minister of Health No. 1096/MENKES/ PERVI/2011 concerning Food Catering Hygiene and Sanitation. Jakarta; (2011)

19. Ministry of Health RI. Ministry of Health Regulation Number 43 Year 2014 About Sanitation Hygiene Drinking Water Depot. Jakarta, Indonesia: Ministry of Health; (2014) 